\title{
Rational Emotive Behavior Therapy (Rebt) Dalam Efeknya Terhadap Frekuensi Inisiasi Konsumsi Rokok Pada Remaja Laki-Laki Di Kota Bengkulu
}

\author{
Tita Septi Handayani ${ }^{1}$, Murwati ${ }^{2}$ \\ ${ }^{1}$ Program Studi Profesi Ners Fakultas Ilmu Kesehatan Universitas Dehasen Bengkulu \\ ${ }^{2}$ Program Studi Ilmu Keperawatan Fakultas Ilmu Kesehatan Universitas Dehasen Bengkulu \\ Jln. Merapi Raya no.43, Kel. Kebun tebeng, Kebun Tebeng, Ratu Agung, Bengkulu 38226 \\ Telp: (0736) 21977. Email : handayani_tita@yahoo.co.id
}

\begin{abstract}
Abstrak
Konsumsi rokok pada remaja umumnya masih dalam fase coba-coba. Remaja yang masih dalam tahap cobacoba merokok memiliki pemikiran irasional yang memicu remaja membenarkan perilaku menghisap rokok. Menghadapi remaja dengan perilaku menyimpang, konseling, terapi kognitif dan emotive menjadi salah satu sarana pemecahan masalah dan komunikasi intensif untuk meluruskan pendapat remaja. Penelitian ini bertujuan untuk mengidentifikasi efek program Rational Emotive Behaviour Therapy (REBT) untuk mengurangi konsumsi rokok remaja. Penelitian ini merupakan experiment desain dengan true experiment randomizedsubject. Populasi dalam penelitian ini adalah siswa SMP kelas VII-IX. Sampel adalah mereka yang pernah merokok dan memiliki skor efikasi diri yang rendah dalam menolak merokok. Responden berjumlah 30 orang yang dibagi menjadi kelompok intervensi dan control. Analisa statistik dengan Wilcoxon Signed Ranks Test menunjukan pada kelompok intervensi terdapat perbedaan yang signifikan pada rata-rata jumlah rokok yang dikonsumsi setiap minggu sebelum dan sesudah intervensi (nilai $\mathrm{p}=0.042$ ). Sedangkan pada kelompok kontrol tidak terdapat perbedaan yang signifikan pada rata-rata jumlah rokok yang dikonsumsi setiap minggu sebelum dan sesudah intervensi (nilai $\mathrm{p}=0.726$ ). Penelitian ini menunjukan kesimpulan bahwa Rational Emotive Behaviour Therapy (REBT) efektif untuk menurunkan rata-rata jumlah konsumsi rokok mingguan pada remaja.
\end{abstract}

Kata kunci : Konsumsi Rokok Mingguan, Rational Emotive Behaviour Therapy (REBT), Remaja

\begin{abstract}
Cigarette consumption in adolescents is generally still in the trial and error phase. Adolescents who are still trying to smoke have an irrational thought that triggers the adolescents to justify smoking. Dealing with adolescents with deviant behavior, counseling on cognitive and emotive therapy is one of the means of solving problems and intensive communication to correct adolescents' opinions. This study aims to identify the effects of Rational Emotive Behavior Therapy (REBT) programs to reduce the average number of cigarettes consumed by adolescents. This research is a design experiment with a randomized-subject true experiment. There were 30 respondents divided into intervention and control group. The population in this study were junior high school students in class VII-IX. Samples were those who had smoked and had lower score in refusing smoking. The results of statistical analysis were analyzed using the Wilcoxon Signed Ranks Test showed that in the intervention group there were significant differences in the average number of cigarettes consumed every week before and after the intervention ( $p$ value $=0.042$ ). Whereas in the control group there was no significant difference before and after the intervention $(p=0.726)$. This study shows that REBT is effective in reducing the average number of weekly cigarette consumption in adolescents.
\end{abstract}

Keywords $\quad$ : Adolescent, Rational Emotive Behavior Therapy (REBT), Weekly Cigarette Consumption 


\section{Pendahuluan}

Merokok adalah tindakan membakar ujung puntung tembakau dan menghisapnya. Merokok adalah salah satu masalah terbesar di banyak Negara berkembang bahkan masih menjadi fokus kesehatan Negara maju. ${ }^{1}$ Diawali dari budaya kuno menghisap rokok untuk tujuan kesehatan dan pengobatan, merokok saat ini berkembang menjadi perilaku addictive yang membahayakan kesehatan tidak hanya bagi orang yang mengonsumsi rokok, namun juga bagi orang lain yang tidak merokok tapi menghirup asap dan residu rokok.

Perilaku merokok tidak hanya dilakukan orang dewasa, remaja pun sudah sejak lama menjadi target sasaran konsumen rokok. Rokok dengan sifat dan kandungannya yang menyebabkan efek ketagihan membuat remaja beresiko menjadi konsumen tetap seiring dengan bertambahnya usia. Perilaku menghisap rokok pada remaja diawali dari mencoba karena penasaran, tergoda ajakan teman, terpengaruh iklan dan rokok, atau meniru dari orang yang sudah lebih dulu merokok. $^{2}$ Pada remaja, merokok dilakukan dari sembunyi-sembunyi ketika sedang sendirian atau bersama-sama dengan teman lain yang juga merokok. Berbeda dengan orang dewasa, merokok bukanlah dirasa sebagai suatu kebutuhan atau perasaan kurang lengkap jika tidak dilakukan, namun merokok pada remaja lebih dianggap sebagai suatu tindakan yang mengharapkan pengakuan, identitas diri atau pemenuhan rasa penasaran. ${ }^{3}$ Hal ini berdampak pada jumlah rokok yang dikomsumsi oleh remaja sebagai perokok coba-coba tidaklah sebanyak jumlah rokok yang dihisap oleh perokok rutin pada usia yang lebih tua. Pada remaja yang masih belum menghisap rokok secara rutin, tindakan pencegahan atau penghentian masih sangat potensial untuk dilakukan. faktor kelabilan emosi dan seringkali alasan yang tidak rasional dalam merokok menjadi peluang dalam membuat strategi intervensi yang tepat pada remaja. ${ }^{4}$

Umumnya program pendidikan tentang perilaku beresiko tidak dimasukkan dalam kurikulum utama pendidikan, materi hanya diberikan sebagai muatan tambahan. Hal ini dapat menjadi penyebab kurang efektifnya program pendidikan konvensional dalam mencegah rokok pada siswa remaja.

Salah satu intervensi yang tepat pada remaja yang berperilaku menyimpang adalah dengan konseling. Konseling adalah metode tertutup antar individu yang dilakukan dengan adanya komunikasi dua arah antara remaja sebagai konseli dan perawat sebagai konselor. ${ }^{5}$ Hal ini dinilai sebagai point yang crusial yang akan melewati batas karakteristik remaja yang tidak suka dilarang dan cenderung memberontak Pendapat, curahan hati dan pemikiran remaja sangat penting dalam menentukan sisi mana yang dapat dimasuki oleh perawat dalam mengisi kekosongan pemahaman dan irrasionalitas. Konseling di sekolah umumnya dilakukan oleh guru BP, pembina UKS (Usaha Kesehatan Sekolah) atau perawat sekolah. ${ }^{6}$

Salah satu tehnik konseling yang dapat merubah pemikiran dan membawa pada perubahan perilaku adalah Rational Emotive Behavior Therapy (REBT). REBT mengedepankan pada tehnik konseling yang menggali nilai-nilai irrasional dan yang bersifal emosi lalu mengintervensi dengan alasan-alasan rasional yang akan menggiring pada rasionalitas. Selain itu, adanya system penugasan yang menstimulus kognitif untuk melakukan perilaku yang rasional. ${ }^{7}$ Maka dari itu, terapi ini diharapkan dapat mempengaruhi pemikiran remaja tentang perilaku merokok dan diwijudkan dalam perilaku yang mengurangi konsumsi rokok. Tujuan dari penelitian ini adalah untuk mengetahui efek Rational Emotive Behavior Therapy (REBT) dalam mengurangi rata-rata konsumsi rokok mingguan pada siswa remaja laki-laki 


\section{Metode}

Penelitian ini merupakan experiment desain dengan true experiment randomized-subject, control group pretestposttest design. Teknik sampling pada penelitian ini menggunakan metode purposive sampling dan simple random sampling. Total respondent yang bergabung dalam penelitian ini berjumlah 30 orang. Responden dibagi menjadi dua kelompok, yaitu 15 orang pada kelompok eksperimen yang menerima perlakuan Rational Emotive Behaviour Therapy (REBT) dan 15 orang pada kelompok kontrol yang tidak menerima perlakuan Rational Emotive Behaviour Therapy (REBT) (pendidikan konvensional). Kriteria inkluasi diantaranya konsumsi rokok minimal 1 batang dalam sehari, berkeinginan ikut dalam penelitian, serta responden dan orang tua/wali menandatangani assent form dan inform consent untuk mengikuti penelitian. Apabila ternyata Respondent sudah pernah mengikuti kegiatan sejenis pada kurun waktu 6 bulan sebelumnya maka akan dikeluarkan. Responden dinyatakan dropout jika tidak mengikuti seluruh atau salah satu sesi kegiatan pre-test dan atau post-test, serta tidak mengisi Lembar kuesioner dengan lengkap. Respondent menuliskan Jumlah rata-rata konsumsi rokok mingguan pada kuesioner. Jawaban sangat bervariasi mulai dari 0 (tidak sama sekali) hingga tak terbatas. Semakin tinggi jumlah rokok yang di konsumsi artinya semakin sering konsumsi rokok setiap minggunya. This study was conducted after gaining ethical clearance from ethical committee board. responden dipilih dari seluruh siswa laki-laki pada satu sekolah menengah pertama (SMP) yang telah di screening dan memenuhi kriteria inklusi. Lalu responden mendapat penjelasan dan surat infomasi penelitian yang ditujukan pada orang tua. Responden yang setuju dan mendapatkan ijin dari orang tua/wali untuk mengikuti penelitian mengembalikan lembar inform consent dan assent form yang telah ditandatangani. Lalu, respondent pada kelompok experiment mengikuti program Rational Emotive Behavior Therapy (REBT) yang terdiri 4 sesi dan berlangsung selama 60 - 90 menit setiap sesi. Program dilakukan satu minggu sekali selama 4 minggu. Pada waktu yang bersamaan Kelompok control tidak menerima program yang sama. Setelah program selesai, kedua kelompok kembali mengisi pertanyaan kuesioner yang sama.

\section{Hasil}

Total 30 respondent yang menghisap rokok minimal 1 batang perminggu dibagi menjadi dua kelompok. Kelompok experiment menerima program Rational Emotive Behavior Therapy (REBT), sedangkan kelompok control tidak menerima (pendidikan konvensional). Jumlah rokok di tanyakan sebelum dan sesudah intervensi.

Tabel 1. Perbedaan rata-rata jumlah konsumsi rokok antar kelompok $(\mathrm{n}=30)$

\begin{tabular}{cccc}
\hline Kelompok & Intervensi & Kontrol & $\boldsymbol{p}$ \\
\hline Pre & $6.87(5.975)$ & $5.60(5.974)$ & .327 \\
\hline Post & $4.00(3.117)$ & $5.33(5.715)$ & .752 \\
\hline
\end{tabular}

Table 1 menunjukkan bahwa sebelum responden mengikuti intervensi rata-rata konsumsi rokok mingguan adalah 6.87 pada kelompok ekperimen dan 5.60 pada kelompok control. Selain itu, table 1 juga menunjukkan bahwa tidak ada perbedaan yang signifikan pada rata-rata jumlah konsumsi rokok mingguan antara kedua kelompok $(p=0.327)$. setelah intervensi, kedua kelompok kembali dibandingkan. Dan didapatkan hasil tidak ada perbedaan antara kedua kelompok $(\mathrm{p}>0.05)$. 
Tabel 2. Perbedaan rata-rata jumlah konsumsi rokok pada kelompok sebelum dan setelah intervensi.

\begin{tabular}{cccc}
\hline Kelompok & Pre & Post & $\boldsymbol{P}$ \\
\hline Intervensi & $6.87(5.975)$ & $4.00(3,117)$ & $.042^{*}$ \\
\hline Kontrol & $5.60(5.974)$ & $5.33(5.715)$ & .726 \\
\hline *p $<0.05$ & & & \\
\hline
\end{tabular}

Table 2 menunjukkan rata-rata jumlah konsumsi rokok mingguan pada kelompok ekperimen menurun dari 6.87 (5.975) menjadi $4.00 \quad(3,117)$. Secara analisa statistic dengan uji wilcoxon menunjukkan bahwa terdapat perbedaan signikan ratarata jumlah konsumsi rokok mingguan pada kelompok ekperimen sebelum dan sesudah mengikuti program REBT $(\mathrm{p}=0.042)$, sedangkan pada kelompok control, rata-rata jumlah konsumsi rokok mingguan tidak berubah $(\mathrm{p}>0.05)$.

\section{Pembahasan}

Penelitian menunjukkan program REBT efektif dalam mengurangi rata-rata jumlah konsumsi rokok mingguan. Konsumsi rokok adalah hal yang sudah biasa dilakukan remaja, terutama remaja laki-laki. Konsumsi rokok ini dapat diawali dari coba-coba sebagai perilaku ekperiment. ${ }^{8}$ Perilaku ekperiment merokok pada remaja dapat di dorong oleh berbagai factor, seperti misalnya mencontoh perilaku merokok yang ditunjukkan oleh orang terdekat, reklame dan iklan tentang rokok, kondisi emosional yang belum stabil atau tekanan dari lingkungan. Perokok coba-coba belum menghisap rokok secara rutin dengan jumlah yang bisa diperkirakan. ${ }^{9}$ Perokok coba-coba yang telah merasakan kecanduan akan semakin sering menghisap rokok dan berdampak pada konsumsi rutin harian yang tidak dapat dihindari.
Perilaku merokok pada remaja dihubungkan dengan kondisi psikologi. ${ }^{10}$ Dimana kondisi psikologi ini sangat spesifik berhubungan dengan tumbuh kembang sesuai dengan usia remaja. Karakter pencarian jati diri, kebutuhan terhadap pengakuan dari lingkungan terutama teman dan lawan jenis, kondisi emosi yang labil, memiliki rasa ingin tahu yang tinggi namun juga membuat remaja menjadi individu yang sulit untuk menerima koreksi jika apa yang dilakukan mereka salah. ${ }^{11}$ Hal ini memicu remaja mudah untuk menerima hal-hal menarik yang baru mereka ketahui di usia remaja, seperti perilaku merokok. mitos dan pendapat umum yang berkembang di antara remaja laki semakin menguatkan keinginan remaja untuk merokok. ${ }^{12}$

Rational Emotive Behaviour Therapy (REBT) adalah rangkaian kegiatan yang berfokus pada konseling baik perorangan maupun dalam kelompok kecil. Salah satu strategi yang efektif dalam menghadapi remaja dengan masalah penyimpangan perilaku adalah dengan melakukan pembicaraan secara personal dan bersamasama dengan remaja membongkar rasionalitas pada perilaku yang dilakukannya. ${ }^{13}$ Penuduhan dan sikap menghakimi orang dewasa terhadap remaja yang merokok tidak seiring sejalan dengan fase tumbuh kembang yang sedang terjadi pada diri remaja.14 .Proses konseling bersama konselor yang dilakukan secara tertutup, membangun kepercayaan remaja untuk berkomunikasi secara terbuka dengan counselor. Kepercayaan dan keterbukaan yang terbangun sejak awal dengan menghindari penuduhan dan penyalahkan remaja atas perilakunya akan membuka gerbang dalam penggalian alasan dibalik perilaku tersebut. ${ }^{15} \mathrm{Hal}$ ini mendatangkan keuntungan bagi konselor, umpan balik yang positif dari remaja membuka peluang penerimaan terhadap tahap konseling berikutnya, yaitu proses meluruskan pemikiran yang irrasional dan membangun perilaku. Pada tahap ini 
rangsangan terhadap penugasan dan latihan penguasaan emosi berpengaruh positive pada konsumsi rokok remaja.

Dampak nyata yang dapat dilihat dalam pengaruh REBT terhadap perilaku rokok yaitu berkurangnya rata-rata rokok yang dikonsumsi sesudah mengikuti program konseling REBT. $^{16}$ Remaja sebagai perokok coba-coba terkadang tidak menghisap rokok setiap hari, karena banyak factor dari luar yang mempengaruhi dan kondisi dari dalam yang kadang mendorong untuk menghisap rokok. ${ }^{17}$ Karena itu konsumsi mingguan dinilai dapat cukup mewakili karakter remaja sebagai perokok coba-coba.

\section{Kesimpulan}

Hasil dari penelitian ini menunjukkan bahwa Rational Emotive Behavior Therapy (REBT) efektif dalam menurunkan rata-rata konsumsi mingguan rokok pada remaja laki-laki. Rational Emotive Behavior Therapy (REBT) dapat menjadi salah satu program yang diterapkan pada bagian Usaha Kesehatan Sekolah (UKS) dan Program Puskesmas dalam menekan perilaku merokok pada remaja.

\section{Saran}

Kelompok potensial sekaligus beresiko untuk memulai konsistensi merokok berasal dari kelas rendah. Ada baiknya, penguatan pencegahan merokok dimulai dari kelas rendah atau kelas VII. Karena semakin tinggi kelas akan semakin sulit merubah perilaku. Konseling individu atau konseling kelompok kecil dapat menjadi alternative dalam intervensi pencegahan perilaku merokok pada remaja khususnya remaja laki-laki.

\section{Daftar Pustaka}

1. Nurmiyanto A, Rahmani D. Sosialisasi Bahaya Rokok Guna Meningkatkan Kesadaran Masyrarakat Akan Besarnya Dampak Buruk Rokok Bagi Kesehatan. Jurnal Inovasi dan Kewirausahaan. 2013. 224;232-2.
2. Sarino, Ahyanti M. Perilaku Merokok Pada Remaja SMP. Jurnal Keperawatan. 2012; p. 148-155.

3. Munir, M. Pengetahuan Dan Sikap Remaja Tentang Risiko Merokok Pada Santri Mahasiswa Di Asrama UIN Sunan Ampel Surabaya. Klorofil. 2018. 1 (2): p. 93-104.

4. Swastikawara S, Laturrakhmi YF, Oktaviani FH. Intervensi Perilaku Sadar Bahaya Rokok Melalui Humor Dan Rational Based Message Appeals. Jurnal Studi Komunikasi. 2018. 02 (1) : p. 68-87.

5. Budisetyani I. G. A. P. W, dkk. Bahan Ajar Psikologi Konseling. 2016

6. Martunus. Peran Pelaksana Usaha Kesehatan Sekolah Dalam Kesehatan Anak SD Negeri No.026 Simpang Tiga Kecamatan Loa Janan Ilir. eJournal Ilmu Sosiatri. 2013. 1 (2): p. 51-64

7. Erlina N, Sari DN. Pengaruh Pendekatan Rational Emotive Behaviour Therapy (REBT) Terhadap Peningkatan Kecerdasan Emosional Pada Peserta Didik Kelas VIII SMPN 6 Bandar Lampung Tahun Ajaran 2015/2016. Jurnal Bimbingan dan Konseling. 2016.03 (2) : p. 303316.

8. Astuti K. Gambaran Perilaku Merokok Pada Remaja Di Kabupaten Bantul. INSIGHT. 2012. 10 (1) : p. 77-87.

9. Rosita R, Suswardany DL, Abidin Z. Penentu Keberhasilan Berhenti Merokok Pada Mahasiswa Fakultas Ilmu Kesehatan Universitas Muhammadiyah Surakarta. Juenal Kesehatan Masyarakat. 2012.8 (1): p. 1-10.

10. Wulan DK. Faktor Psikologis Yang Mempengaruhi Perilaku Merokok Pada Remaja. Humaniora. 2012.3 (2): p. 504-511.

11.Sarmin. Konselor Sebaya: Pemberdayaan Teman Sebaya Dalam Sekolah Guna Menanggulangi Pengaruh Negatif Lingkungan Brilliant. Jurnal Riset dan Konseptual. 2017. 2 (1) : p. $102-112$.

12. Febri B. Perilaku Remaja Pecandu Rokok Siswa SMP Di Desa Gunung Kesiangan Kecamatan Benai Kabupaten Kuantan Singingi. JOM FISIP. 2016. 3 (2).

13.Iqbal M. Penanggulangan Perilaku Menyimpang. Lentera Pendidikan. 2014. 17 (2) : p. 229-242.

14. Peter R. Peran Orangtua Dalam Krisis Remaja. Humaniora. 2015. 6 (4) : p. 453-460

15. Negoro SH. Pembentukan Sikap Oleh Perokok Remaja Melalui Peringatan Bahaya Merokok Pada Kemasan Rokok. JURNAL INTERAKSI. 2016. 5 (2) ; p. 112-122

16. Tahir A, Oktaviana D. Pendekatan Konseling Behavior Dengan Teknik Self Control Untuk Mengurangi Kebiasaan Merokok Pada Peserta Didik Di SMA Negeri 13 Bandar Lampung. Konseli: Jurnal Bimbingan dan Konseling. 2016. 03 (1); p. 63-77 
17. Tristansi I. Remaja Dan Perilaku Merokok. The 3rd Universty Research Colloquium. 2016. p : $328-342$. 